\title{
Strategies for Effective Management of Health and Safety in Confined Site Construction
}

\begin{abstract}
The overall aim of this research is to identify and catalogue the numerous managerial strategies for effective management of health and safety on a confined, urban, construction site. A mixed methods methodology was adopted using interviews and focus group discussions on three selected case studies of confined construction sites. In addition to these, a questionnaire survey was used based on the findings from the interviews and the focus group discussions. The top five key strategies include (1) Employ safe system of work plans to mitigate personnel health and safety issues; (2) Inform personnel, before starting on-site, of the potential issues using site inductions; (3) Effective communication among site personnel; (4) Draft and implement an effective design site layout prior to starting on-site; and (5) Use of banksman (traffic co-ordinator) to segregate personnel from vehicular traffic. The construction sector is one of the leading industries in accident causation and with the continued development and regeneration of our urban centres, confined site construction is quickly becoming the norm - an environment which only fuels accident creation within the construction sector. This research aids on-site management that requires direction and assistance in the identification and implementation of key strategies for the management of health and safety, particularly in confined construction site environments.
\end{abstract}

Keywords City centre development, Personnel management, Project management, Productivity, Urban development

\section{Introduction}

The global construction industry is noted as being one of the most hazardous environments in which to work (Cheah 2007) and worldwide accounts for at least 60,000 workplace deaths a year (International Labour Organisation 2005), resulting in construction workers being three times more likely to be killed and twice as likely to be injured as workers in other occupations (European Agency for Safety and Health at Work 2001). Within the European Union, there are more than 1,300 fatalities in the construction sector each year (European Agency for Safety and Health at Work 2000). This statistic indicates the severity of the issue and as a result, it is also illustrates that the level of workplace accidents in the construction sector is unacceptably high and requires redress (European Agency for Safety and Health at Work 2011).

In the United Kingdom, the construction industry reflects this trend and remains the most dangerous industry in terms of accidents, exceeding all other land based sectors (Health and Safety Executive 2010a). Accidents and occupational health problems have been widely acknowledged traits in the industry (Ringen \& Seegal 1995; Hyoung et al. 2009; Pinto, et al. 2011) but on a more positive note, over the last five years, the United Kingdoms' Health and Safety Executive (2010b) has noted a decrease in the accident rate of fatal injuries in the workplace. Due to the long-term adverse effects of these safety hazards and the legal requirement for the industry to protect its most important asset - its personnel (Egan 1998), it is essential that appropriate strategies are developed to proactively offset some of these health and safety issues on-site, thus safe guarding the safety of those within the industry (Loosemore et al. 2003). 
In conjunction with other factors, a limited spatial environment has been identified as one of the core contributing attributes, resulting in accidents on-site (International Labour Office 1999). One such environment which excels in this regard is that of urban, inner city, confined construction sites. Caused by the continued development of urban, inner cities along with the verticalisation and modernisation of existing structures (Harvey 2006), the prevalence of such confined site environments is set to continue for the foreseeable future (United Nations 2008; United Nations 2010). With confined site construction, one of the core attributes is the intrinsic lack of space in which project management professionals must successfully manage and deliver projects while site operatives must carry out activities safely (Atkin 2003; Winch 2010). The effective management of this inherently hazardous environment is essential; therefore, appropriate strategies must be identified to enable its effective management by site management professionals. Identifying appropriate strategies in the supervision of an inherently diverse and problematic environment, such as that of an inner city confined construction site, on-site professionals can strive to achieve an unblemished health and safety record, particularly with regards to the construction of complex structures within a spatially limited environment. The humanitarian, legal and economic savings, both direct and indirect, to the industry would be profound (Leopold \& Leonard 1987; Wideman 1990), thereby ensuring the continued competitiveness of the sector, particularly in the current challenging economic recession.

Hence, the main objective of this paper is to identify and catalogue the numerous managerial strategies for effective management of health and safety on a confined construction site. The leading research question posed is: what are the top critical strategies in health and safety management of site personnel on a confined construction site? In order to meet the objective and provide solutions to the research question, a mixed methods research approach is undertaken. The resulting data is analysed and discussed, with conclusions provided, paying particular attention to implication for practice.

\section{Confined Site Construction}

Confined site construction differs from standard, spatially unrestricted construction projects mainly due to one characteristic - space. In cases where urban construction of parks and recreation areas is concerned, the spatial limitations associated with other urban development's incorporating buildings/structures are avoided, due to the abundance of space in which to effectively manage the project. In the case of confined site construction, this environment is different. Inner city, urban developments are often characterised by the lack of space in which project management professionals must successfully construct often intricate structures, with little room to safely co-ordinate the works, under increasingly compressed schedules and deadlines (Wideman 1990; Long, et al. 2004; Winch 2010). In the vast majority of cases, the building structure occupies the majority of the site, leaving limited space to accommodate the various activities and facilities required to complete the project work (Tindiwensi 2000).

Confined construction sites vary to that of open spaced construction sites by reduced productivity (Ogunlana et al. 1999), increased schedule compression (Sharma 2009), material management (Spillane et al. 2010a) and most importantly - health and safety (Spillane et al. 2009). With regards to research on health and safety, the vast majority of literature reviews the topic in relation to spatially enriched construction site environments (Sawacha et al. 1999; Mohamed 2002; Haslam et al. 2005; Ng et al. 2005; Teo et al. 2005). Furthermore, Sahli and Armstrong, (1992) Holroyd (1999) and the Health and Safety Authority (2001), among others, all express concerns in relation to confined space construction but fail to acknowledge the greater concern of whole construction projects being constructed on sites where space is a finite resource requiring effective management. In such cases, the vast majority of research fails to adequately develop strategies to mitigate the problems prevalent (Sahli \& Armstrong 1992; Holroyd 1999; Health and Safety Authority, 2001; Lambeck \& Eschemulle 2008). Burch (1985) outlines "the planning and organisational

Spillane, J and Oyedele, L (2013) 'Strategies for effective management of health and safety in confined site construction', Australasian Journal of Construction Economics and Building, 13 (4) 50-64 
problems associated with confined sites' where the problems associated with pre-tender and pre-contract planning are discussed and not the actual management of the spatial restrictions present, and more importantly - the resulting health and safety constraints in existence. Lambeck and Eschemuller (2008) reveal some of the problems associated with health and safety on confined construction sites but the overall result lacks solutions on how to effectively resolve the issue.

In a related development, when reviewing the topic of confined site construction, the subject is often confused with that of confined space within a construction site. The latter is defined by the Occupational Safety and Health Administration (2004) as a specific area on-site where works are being carried out that is large enough for an employee to enter; is not designed for continuous occupancy by the employee and has limited means of entry or exit.' With regards to confined site construction, no prescribed definition exists in literature. Hereafter, a confined construction site is defined as 'a site where permanent works fit the site footprint, extending to levels above and/or below ground level, leaving spatial restrictions for other operations (e.g. personnel, plant and material movements, materials storage and temporary accommodation etc.) and require effective resource co-ordination beyond normal on-site management input.' Existing literature has only examined confined spaces on-site and not confined site construction in respect to health and safety (Holt 2005; Buskin \& Paulozzi 1984; Mitropoulos et al. 2005). In cases where the topic of confined site construction is addressed, little information is provided (Kelsey et al. 2001) and where such information is documented, the lack of detail is evident (Burch 1985; Roberts \& Sykes, 2000; Lambeck \& Eschemuller 2008). The absence of substantial research in the area, particularly in relation to health and safety, needs to be addressed, especially due to its prominent nature in today's construction sector.

\section{Methodology}

In order to compile an exhaustive list of strategies in the management of health and safety on a confined construction site, a number of data collection techniques were adopted. A mixed method approach was used, incorporating qualitative (literature review and case studies [individual interviews and focus groups]) and quantitative (questionnaire survey) methods of data collection and analysis, aiding in the validation of results through triangulation by combining numerous methodologies in the study of the same research topic (Denzin 1978).

\section{Case Studies}

To aid in the data collection process and to unearth the on-site management issues, various existing confined construction sites were required. Selective sampling is employed over random, convenience or modified sampling for the case study selection process, as the most informative, suitable and beneficial case study examples were chosen, based on set criteria and characteristics (Muslea et al. 2000; Westfall 2009). To highlight suitable case studies, professional member bodies were approached, including the APM (Association for Project Management), CIOB (Chartered Institute of Building), RICS (Royal Institute of Chartered Surveyors) and the PMI (Project Management Institute) along with the corresponding local chapters associated within each of these institutes.

One of the key criteria used in the pre-selection of the case studies was the inclusion of the definition for a confined construction site, as outlined earlier. This definition, in conjunction with a detailed review of the site plans, aided in the shortlisting and the ultimate selection of the case studies identified. To further aid and complement the selection process, each of the potential case studies identified were classified based on the structure being constructed, its geographical location, the percentage of the site occupied by the building structure and the overall difficulties exhibited in the project being constructed. From a selection process that involves twelve possible case studies, three case studies from Northern Ireland (L'Derry),

Spillane, J and Oyedele, L (2013) 'Strategies for effective management of health and safety in confined site construction', Australasian Journal of Construction Economics and Building, 13 (4) 50-64 
the Republic of Ireland (Limerick) and the USA (Chicago, Illinois) were chosen, incorporating underground service works, low rise apartment/office units and high rise condominiums, respectively, where the first case study was at $75 \%$ completion, the second at $100 \%$ and the third $90 \%$.

\section{Interviews and Focus Groups}

To complement and further aid the investigative nature of the research, supplementary qualitative analyses in the form of individual interviews and focus groups discussion was conducted. Both methods of data collection were chosen due to the close interaction achieved, both individually and collectively, with numerous construction personnel in various hierarchical levels, based in various locations. An average of eight participants contributed within each of the focus group discussions, varying from site operatives to construction directors, including site managers, site engineers, project managers, quantity surveyors, bid managers, programme and portfolio managers. On average, the participants had twelve years confined site construction experience, under various types of projects, in numerous geographical locations. The focus group durations ranged from twenty to seventy five minutes, with the average duration being in excess of forty minutes.

In the case study in Northern Ireland, three individual interviews were undertaken with the site manager, project manager and site engineer. Subsequently, a focus group was held later that day with the aforementioned participants in addition to two site operatives, a quantity surveyor and programme manager. The case study in the Republic of Ireland included individual interviews with the programme manager, portfolio manager and a quantity surveyor. Two focus groups were undertaken on this project, due to time and location constraints. The first focus group participants were the programme manager, portfolio manager and a quantity surveyor in addition to two project managers, two bid managers and two site managers. The second focus included four general operatives, three site managers, two site engineers and the on-site project manager. Finally, the individual interviews for the third case study (USA) included the bid managers, programme and portfolio managers, who also participated in the focus group discussion in conjunction with the bid manager and two quantity surveyors. With regards to the case studies in the Republic and Northern Ireland, the interviews and focus groups were conducted on-site. The third case study review was conducted in the developers head office, where various members of the project team were in attendance. Three types of interview procedures were considered (unstructured, semi-structured and structured). Semi-structured interview protocol was selected due to the conversational naturel; thus providing a relaxed environment, which encourages honesty and openness from the interviewee (Laurier 2010).

As a result, a holistic overview of the numerous factors associated with health and safety of construction personnel was attained, thus aiding in the identification of the core attributes with regards to the research topic. The individual interviews assisted in the data collection process due to the one-to-one nature of the interviews while the focus group discussion aided, through a synergistic process, in affirming the inclusion of the factors identified earlier coupled with assisting in the clarification and identification of further factors worthy of consideration. The focus group interactions assisted in the removal of bias from all parties participating while also aiding the contributors to identify additional factors that may not have been highlighted during individual interviews conducted in isolation. From the qualitative analysis of the case studies, individual interviews and the focus groups discussion, a total of eighteen factors were highlighted and employed in the questionnaire survey.

\section{Questionnaire Survey}

To assist in the quantification and classification of the factors highlighted thus far, quantitative analysis using a questionnaire survey is recommended (Mohamed 2002), particularly in the case of quantifying health and safety factors (Ojanen et al. 1988). Prior to

Spillane, J and Oyedele, L (2013) 'Strategies for effective management of health and safety in confined site construction', Australasian Journal of Construction Economics and Building, 13 (4) 50-64 
circulation, the questionnaire was piloted with three individuals (a project manager, site manager and programme manager) to quantify the level of reliability and validity of the survey. The individuals chosen for the pilot study were contacted based on selective and convenience sampling and were from a project management, site management, site engineer and construction management backgrounds and have an average of ten years confined site construction experience. This provided a holistic overview of the various respondents targeted by the survey coupled with aiding the research team in the affirming the suitability of the questionnaire for circulation.

Each of the factors is included in statement form, where the respondents are asked to rate the issue highlighted under two distinctive parameters. 'Importance' and the 'Frequency of occurrence' with each on a Likert scale from 1 to 5 , where 1 was 'not important' and 'not frequent' and 5 were 'most important' and 'most frequent' respectively. This aided in quantifying the significance of each of the issues based on the importance but also the frequency of occurrence of the factors questioned.

On circulating the questionnaire, again various companies and professional bodies were approach and their corresponding members contacted with regards to the completion of the questionnaire survey. In total, 216 questionnaires were circulated, based on random sampling of contacts collected from the APM and the CIOB. 105 questionnaires were returned with usable data, giving a return ratio of $49.1 \%$. Of the 105 questionnaires returned, contracts managers, $(20 \%)$, project managers, $(15 \%)$, site managers $(24 \%)$, project engineers (10\%) quantity surveyors $(9 \%)$ and senior site managers $(7 \%)$ attributed to the overall classification of industry professionals with an additional $15 \%$ accounting for architects, health and safety officers and plant managers.

\section{Analysis}

The data attributable to the factors questioned is assessed based on importance index, frequency index and significance index. All the formulas were derived from similar studies in construction management and include Okpala and Aniekwu (1988), Elinwa and Joshua (2001), Chan and Kumaraswamy (2002) and Field (2005). The formulas include;

Importance Index $(I I)=\left\{\frac{\sum(i)}{\mathrm{NI}}\right\} \times 100 \%$

Equation 1)

Frequency Index $(F I)=\left\{\frac{\sum(f)}{\text { NF }}\right\} \times 100 \%$

Equation 2)

Significance Index $(S I)=\left\{\frac{\sum(\text { if })}{\text { NIF }}\right\} \times 100 \%$

Equation 3)

In the three index equations, $i$ is the importance weighting and $f$ is the frequency of occurrence weighting assigned by the respondents in the questionnaire, rating from one to five. I and $\mathrm{F}$ are the highest ratings possible for each of the assigned factors; in both cases, this is five. $\mathrm{N}$ is the total number of respondents with usable data to that particular factor, which is 105. Table 1 shows the list of all the eighteen strategies and their associated importance index (II), frequency index (FI) and significance index (SI) along with their rankings.

As the table documents, where a factor is considered to be important, but the frequency of it being implemented is low, its overall pragmatism is called into question. In lieu, where a

Spillane, J and Oyedele, L (2013) 'Strategies for effective management of health and safety in confined site construction', Australasian Journal of Construction Economics and Building, 13 (4) 50-64 
factor is ranked as being both important and having a high frequency of being implemented, then it is ranked as being an efficient strategy in the management of health and safety on a confined construction site. As a result, it is possible to highlight the factors that are not only important, but also are frequently implemented strategies in the management of health and safety. The top five strategies in the table based on their level of significance index are:

(i) Employ 'Safe System of Work Plans' to mitigate personnel health and safety issues

(ii) Inform personnel, before starting on-site, of the potential issues using site inductions

(iii) Effective communication among site personnel

(iv) Draft and implement an effective design site layout prior to starting on-site

(v) Use a banksman (traffic co-ordinator) to segregate personnel from vehicular traffic

\section{Discussion}

Each of the top five strategies in the management of health and safety on a confined construction site is discussed in further detail below, starting with the top most strategies;

\section{Employ Safe System of Work Plans to Mitigate Personnel Health and Safety Issues}

This particular factor is ranked first with a prominent significance $(81.5 \%)$, Importance $\left(2^{\text {nd }}\right)$ and Frequency $\left(2^{\text {nd }}\right)$ indexes. This indicates that this factor is not only important but is also frequently used as an effective strategy to enable effective health and safety on construction site. The use of safe system of work plans and method statements complements the safety statement which is in place for all developments, regardless of the type of environment. The Health and Safety Executive (2009a), gives clear and concise information on the uses and benefits of the implementation of a safe system of work plan, resulting in the mitigation or elimination of possible adverse scenarios, which may cause accident or injury. Due to the inherent lack of space on a confined construction site, the possibility for increased accidents or incidents is exasperated (Spillane et al. 2010b), therefore it is essential that an effective means by which to eliminate, mitigate or transfer the possible risks through drafting an effective risk identification and method statement, ultimately leading to a safe system of work plan.

The Health and Safety Authority (2011) identifies the primary objective of a safe system of work plan to 'identify the major hazards associated with your work activities and to ensure that appropriate controls are in place before work commences'. One of the fundamental points to note is that employers have a common law duty to ensure that a safe system of work plan is in place, prior to the work being started on-site (Shain 2004). It is evident that not only must a safe system of work be produced, but it must also be implemented. Haslam et al. (2005) indicates that 'where safety depends on communication and coordination, it is important that a robust safe system of work is established', while Carter and Smith (2006) echo this point though identifying that an effective system of work is essential, particularly the improvement within the industry of hazard identification though the use of safe system of work plans.

Cooper (2006) argues that where there is a lack of formal protocol in the development and implementation of safe system of work plans, this can result in unsafe behaviour while carrying out the hazardous task in question. Gibb et al. (2006) highlight this point by indicating that where a safe system of work is void, there is an increased propensity for accidents or incidents to occur, therefore, it is an essential requirement, both legally and productively, to incorporate a safe system of work plans into a construction project, but particularly one where the surrounding environment provides additional adverse working conditions as that of a confined construction site.

Spillane, J and Oyedele, L (2013) 'Strategies for effective management of health and safety in confined site construction', Australasian Journal of Construction Economics and Building, 13 (4) 50-64 


\begin{tabular}{|c|c|c|c|c|c|c|c|}
\hline & List of Strategies & $\begin{array}{c}\text { Importance } \\
\text { Index - II } \\
(\%)\end{array}$ & $\begin{array}{c}\text { Importance } \\
\text { Ranking - } \\
\text { IR }\end{array}$ & $\begin{array}{l}\text { Frequency } \\
\text { Index - FI } \\
(\%)\end{array}$ & $\begin{array}{c}\text { Frequency } \\
\text { Ranking - } \\
\text { FR }\end{array}$ & $\begin{array}{c}\text { Significance } \\
\text { Index - SI } \\
(\%)\end{array}$ & $\begin{array}{l}\text { Significance } \\
\text { Ranking (SI) }\end{array}$ \\
\hline 1 & $\begin{array}{l}\text { Employ 'Safe System of Work Plans' to mitigate personnel health and } \\
\text { safety issues }\end{array}$ & 84.20 & 2 & 78.90 & 2 & 81.50 & 1 \\
\hline 2 & $\begin{array}{l}\text { Inform personnel, before starting on-site, of the potential issues using site } \\
\text { inductions }\end{array}$ & 81.50 & 4 & 80.70 & 1 & 81.10 & 2 \\
\hline 3 & Effective communication among site personnel & 84.40 & 1 & 74.20 & 4 & 79.30 & 3 \\
\hline 4 & Draft and implement an effective design site layout prior to starting on-site & 78.40 & 6 & 75.80 & 3 & 77.10 & 4 \\
\hline 5 & $\begin{array}{l}\text { Use a banksman (traffic co-ordinator) to segregate personnel from } \\
\text { vehicular traffic }\end{array}$ & 82.20 & 3 & 71.50 & 8 & 76.80 & 5 \\
\hline 6 & $\begin{array}{l}\text { Conduct regular site meetings to inform personnel of the external issues } \\
\text { on-site }\end{array}$ & 78.90 & 5 & 72.00 & 5 & 75.50 & 6 \\
\hline 7 & $\begin{array}{l}\text { Draft a method statement for high risk delivery of plant and materials to } \\
\text { site }\end{array}$ & 77.60 & 7 & 71.60 & 7 & 74.60 & 7 \\
\hline 8 & Draft and implement method statements to aid personnel management & 76.90 & 8 & 72.00 & 6 & 74.50 & 8 \\
\hline 9 & $\begin{array}{l}\text { Use dust suppression (watering down) to reduce the effects of dust on } \\
\text { neighbours }\end{array}$ & 74.40 & 11 & 70.90 & 9 & 72.70 & 9 \\
\hline 10 & Use signage to aid the movement of personnel in and around site & 75.30 & 10 & 69.30 & 10 & 72.30 & 10 \\
\hline 11 & $\begin{array}{l}\text { Review location of the site entrance to facilitate safe access \& egress for } \\
\text { personnel }\end{array}$ & 76.70 & 9 & 65.50 & 12 & 71.10 & 11 \\
\hline 12 & Erect debris netting to reduce the levels of dust and debris exiting the site & 71.80 & 14 & 66.90 & 11 & 69.40 & 12 \\
\hline 13 & $\begin{array}{l}\text { Use noise suppressive plant and equipment to reduce noise levels } \\
\text { produced on-site }\end{array}$ & 72.60 & 13 & 64.20 & 13 & 68.40 & 13 \\
\hline 14 & Address spatial conflict prior to it occurring on-site (Proactive-Vs-Reactive) & 73.70 & 12 & 62.20 & 15 & 67.90 & 14 \\
\hline 15 & $\begin{array}{l}\text { Review and monitor spatial conflict on-site in line with the programme of } \\
\text { works }\end{array}$ & 70.70 & 15 & 62.40 & 14 & 66.60 & 15 \\
\hline 16 & $\begin{array}{l}\text { Reduce out of hours working, to mitigate the effects of noise and vibration } \\
\text { on-site }\end{array}$ & 69.50 & 16 & 62.20 & 16 & 65.90 & 16 \\
\hline 17 & $\begin{array}{l}\text { Monitor the workflow patterns of personnel as works progress and review } \\
\text { as required }\end{array}$ & 65.90 & 17 & 56.20 & 18 & 61.10 & 17 \\
\hline 18 & Use personnel hoists to aid personnel workflow throughout the site & 65.40 & 18 & 56.40 & 17 & 60.90 & 18 \\
\hline
\end{tabular}

Table 1 Strategies for Effective Health and Safety Management in Confined Site Construction and their Rankings

Spillane, J and Oyedele, L (2013) 'Strategies for effective management of health and safety in confined site construction', Australasian Journal of Construction Economics and Building, 13 (4) 50-64 


\section{Inform Personnel, before Starting on-Site, of the Potential Issues Using Site Inductions}

This factor is ranked second with Significance $(81.1 \%)$, Importance $\left(4^{\text {th }}\right)$ and Frequency $\left(1^{\text {st }}\right)$ indexes recorded. Timely information is one of the key aspects in the effective management of personnel in the construction industry and will ultimately impact on the level of safety onsite (Dalton 2002). One of the leading methods to inform personnel of the various health and safety woes present on each particular construction site is through the use of site specific inductions (McDonald \& Hrymak 2002). A site induction provides the initial contact with new individuals entering a construction site, the purpose of which is to provide the individual(s) with an overview of the various site specific safety, health and welfare requirements and associated issues. In addition, a site induction also provides an opportunity to deliver a refresher course to all in attendance, thus honing the health and safety knowledge of those in attendance (Edwards \& Holt 2008). Where on-site personnel have not received a site induction prior to commencing on-site, evidence has indicated that they are a risk both to themselves and to those around them (Rowlinson et al. 2003).

Through introducing and interacting with new personnel entering a confined site, it is possible to improve the level of communication and worker engagement though on-site inductions, thus aiding in the identification of potential hazards on-site (Hare et al. 2005). For half of the personnel employed in the industry, their safety training comprises site induction only and with the majority of site inductions ranging in duration from ten to ninety minutes, this window of opportunity must be utilised to its maximum potential (McDonald \& Hrymak 2002). Sejas (2009) and the Health and Safety Executive (2009a) both highlight a fundamental trait with regards to the site induction by stating that it is one of the most important, yet most underutilised safety aspect of any construction project. To aid in the proliferation of site inductions in the industry, it is now also becoming a legal requirement to provide site induction training to all new personnel entering a construction site, in order to ensure employer compliance with ensuring a safe place of work (Health and Safety Executive 2009b). Evidence suggests that where site inductions are carried out in a meticulous fashion and with a high degree of proficiency, there is a substantial decrease in the record of accidents or incidents on-site (Australian Safety and Compensation Council 2007). Edwards and Holt (2008) conclude that mandatory induction meetings are essential components in the overall strive towards maintaining an unblemished health and safety record - particularly in an hazardous working environment such as that of a construction site.

\section{Effective Communication among Site Personnel}

The third factor attributes include Significance $(79.3 \%)$, Importance $\left(1^{\text {st }}\right)$ and Frequency $\left(4^{\text {th }}\right)$ indexes. Communication is one of the key components with regards to the management of personnel in the construction sector (Loosemore \& Lee (2002). Haslam et al. (2005) identify that improper communication is a fundamental factor in seven percent of accidents on-site while also contributing to a number of additional accidents and incidents reviewed. One of the key conclusions provided is that 'poor communication within work teams contributed to incidents', therefore effective means of communication, including verbally, visual and written must be adhered to at all times. Where misinterpretations occur, there is a propensity for misguided instructions or signals, which may contribute or result in an accident or incident on-site. As a result, the quality of the communication between the parties is also of paramount importance, where the line must be of an acceptable quality to aid in the transfer of the information from one party to the next (Hofmann \& Morgeson 1999).

Interestingly, a number of authors (Kartam et al. 2000); Choudhry \& Fanga 2008; Langford et al. 2008) assert that communication is of profound importance, particularly in the case of ethnic minorities working in the construction sector (Trajkovski \& Loosemore 2006). With five percent of accidents due to personnel on-site coming into contact with moving plant (Haslam

Spillane, J and Oyedele, L (2013) 'Strategies for effective management of health and safety in confined site construction', Australasian Journal of Construction Economics and Building, 13 (4) 50-64 
et al. 2005), it is becoming increasingly important for machine operatives to communicate effectively with fellow workers, to mitigate the possibility of accidents or incidents occurring on-site (Health and Safety Authority, 2008).

Subsequently, there must be a means by which personnel on-site can communicate their views and opinions with regards to the health and safety aspects on-site. This process is aided through developing a safety culture through communication on-site (Hofmann \& Stetzer 1996) and is fostered with the introduction and utilisation of toolbox talks, where site personnel are encouraged to discuss the various issues identified among themselves and also with site management. Where both lateral and vertical communication is evident throughout the organisational structure, there is a propensity for reduced incidents and accidents through effective identification, discussion and implementation of effective protocol, to assist in the mitigation of accidents on-site (Harper et al. 1997; Tan-Wilhelm, et al. 2000). Therefore, it is appropriate to conclude that communication, particularly with regards confined site construction, is an effective strategy, predominantly where the lines of communication are clear and direct, resulting in increased management intervention to reduce accidents and incidents on-site.

\section{Draft and Implement an Effective Design Site Layout prior to Starting on-Site}

This factor is presents prominent Significance $(77.1 \%)$, Importance $\left(6^{\text {th }}\right)$ and Frequency $\left(3^{\text {rd }}\right)$ indexes. Design site layout is fundamental to health and safety and thus, the overall success of a construction project, particularly in relation to sites where the lack of space on-site results in an amplified management interface in the management of the various operations on-site (Tommelein \& Zouein 1993; Hegazy \& Elbeltagi 1999; Tam et al. 2002; Khalafallah \& El-Rayes 2004). The acknowledgement that space and its effective management, is essential to successful project management within the construction industry is evident due to the weighting of importance assigned by many site management professions (Lambeck \& Eschemuller 2008). To maximise the efficiency of this spatial assignment, early contractor involvement is also encouraged (Harris et al. 2006; Guo 2009) coupled with extensive communication among the parties (Mossey 2009), predominantly in the identification and assignment of space prior to commencing on-site (Song et al. 2009).

Mawdesley et al. (2002) identify the reasoning behind drafting a site layout plan prior to commencing on-site. This includes the difficulty in specifying the requirements and assignment of space caused by the complexity and dynamic nature of the construction process coupled with the interchanging nature of the various tasks requiring completion. The site requirements often alter on a daily basis, therefore, finding the optimum layout can often prove difficult, time consuming and may lack effectiveness. Also, the interrelationship with the various work packages can also hinder the design site layout process, due to the countless number of task requiring inclusions and consideration in the design site layout.

\section{Use a Banksman (Traffic Coordinator) to Segregate Personnel from Vehicular Traffic}

The final factor attributes include Significance $(76.8 \%)$, Importance $\left(3^{\text {rd }}\right)$ and Frequency $\left(8^{\text {th }}\right)$ indexes. The construction industry is synonymous with accident creation (Spillane et al. 2011) and one of the leading contributory factors is that of accidents due to personnel coming into contact with moving plant (Health and Safety Executive 2003). One of the most effective means to manage the co-ordination and segregation of personnel from vehicular traffic on-site is through the utilisation of a traffic co-ordinator or banksman (Chaturvedi 2005; Davis \& Tomasin 2005). With the abundance of vehicles and mobile heavy equipment on a standard construction project (Olson et al. 1981) coupled with the poor health and safety record (Mallasi \& Dawood 2002; Tam et al. 2002), the segregation of vehicles and personnel is of paramount importance (Haslam et al. 2005). The routing and segregation of large plant vehicles on-site is of prime significance and must be considered throughout the

Spillane, J and Oyedele, L (2013) 'Strategies for effective management of health and safety in confined site construction', Australasian Journal of Construction Economics and Building, 13 (4) 50-64 
planning and construction phases of a project (Varghese \& O'Connor 1995), particularly in the case of spatially restricted construction site environments (Spillane et al. 2011). To assist in this segregation, both machine operatives and associated subcontractors must liaise with on-site management periodically, particularly where there are a number of possible work packages in progress which may present cause for concern.

Machine operatives should also be made aware of their responsibility both for themselves and also for those around them, through effective and continuous training. Separate specific training is also required in the remit of a traffic co-ordinator, to enable the effective discharge of their duties in an exemplary manner. Through segregating personnel from site traffic, it is envisaged that there would be a reduction of 30 to 50 per cent of fatalities on-site (Haslam, et al. 2005), as the majority of accidents are attributable to personnel coming into contact with a moving vehicle.

\section{Conclusion}

Based on the work, five top key strategies were derived from the 18 identified factors; (1) Employ safe system of work plans to mitigate personnel health and safety issues; (2) Inform personnel, before starting on-site, of the potential issues using site inductions; (3) Effective communication among site personnel; (4) Draft and implement an effective design site layout prior to starting on-site; and (5) Use a banksman (traffic co-ordinator) to segregate personnel from vehicular traffic. Where on-site management are faced with the onerous task of effectively managing spatially restricted site environment, the research conducted and the professionals interviewed, identified numerous strategic proposals. To aid the construction industry in the continuous strive towards an unblemished health and safety record, it is beneficial to incorporate one or more of the strategies highlighted. Where on-site management incorporates the strategies documented, particularly in the case of confined site construction, reductions in accidents and incidents are achievable, with the possibility of increased productivity, reduced downtime and ultimately project success.

\section{References}

Atkin, B., Borgbrant, J. \& Josephson, P.-E. 2003, Construction Process Improvement, WileyBlackwell, UK

Australian Safety and Compensation Council, 2007, National Code of Practice for Induction for Construction Work, Australian Government, Australia

Burch T. 1985, Planning and Organisational Problems Associated with Confined Sites, The Practice of Site Management, Vol. 3, Chartered Institute of Building, Ascot, CIOB, UK

Buskin, S. E. \& Paulozzi, L. J. 1984, 'Fatal Injuries in the Construction Industry in Washington State', American Journal of Industrial Medicine, 11 (4), 453-460

Carter, G. \& Smith, S. D. 2006, 'Safety Hazard Identification on Construction Projects', Journal of Construction Engineering and Management, 132 (2), 197-205

Chan, D. W. M. \& Kuamaraswamy, M. M. 2002, 'Compressing Construction Durations: Lessons Learned from Hong Kong Building Projects' International Journal of Project Management, 20 (1), 23-35

Chaturvedi, P. 2005, Managing Safety: Challenges Ahead - Volume 1, Concept Publishing Company, New Delhi

Cheah, C. Y. J. 2007, 'Construction Safety and Health Factors at the Industry Level: The Case of Singapore', Journal of Construction in Developing Countries, 12 (22), 81-99

Choudhry, M. R. \& Fanga, D. 2008, 'Why Operatives Engage in Unsafe Work Behaviour: Investigating Factors on Construction Sites', Safety Science, 46 (4), 566-584 
Cooper, D. M. 2006, 'Exploratory Analyses of the Effects of Managerial Support and Feedback Consequences on Behavioural Safety Maintenance', Journal of Organizational Behaviour Management, 26 (3), 1-41

Dalton, M. 2002, Fatal accidents in the Irish construction industry 1991-2001: A Survey of Contributory Factors, Health and Safety Authority, UK

Davis, V. J. \& Tomasin, K. 2005, Construction Safety Handbook, Thomas Telford, UK

Dawson, S. 1988, Safety at Work: The Limits of Self-Regulation, CUP Archive, UK

Denzin, N. K. 1978, The Research Act, $2^{\text {nd }}$ Ed, McGraw Hill, USA

Edwards, D. J. \& Holt, G. D. 2008, 'Construction Workers' Health and Safety Knowledge: Initial Observations on some Test-Result Data', Journal of Engineering, Design and Technology, 6 (1), 65-80

Egan, J. 1998, Accelerating Change - A report by the strategic forum for construction, Chaired by Sir John Egan The report of the Construction Task Force to the Deputy Prime Minister, John Prescott, on the scope for improving the quality and efficiency of UK construction, Strategic forum for construction, Department of trade and Industry, England, Crown Copyright, UK

Elinwa, A. U. \& Joshua, M. 2001, 'Time Overrun Factors in Nigeria Construction Industry', Journal of Construction Engineering and Management, 127 (5), 419-425

European Agency for Safety and Health at Work 2000, The State of Occupational Safety and Health in the European Union - Pilot Study ISBN 92-828-9272-7, UK, pp. 1

European Agency for Safety and Health at Work 2001, Accident Prevention in the Construction Sector TE-35-01-287-EN-D, European Agency for Safety and Health at Work: Belgium

European Agency for Safety and Health at Work 2011, The Construction Sector has one of the Worst Occupational Safety and Health Records in Europe Accessed on 29th June, 2011, available at: http://osha.europa.eu/en/sector/construction, pp. 1.

Field, A. 2005, Discovering Statistics using SPSS, $3^{\text {rd }}$ Ed, Sage Publications limited, UK

Gibb, A. G. F., Haslam, R., Gyi, D. E., Hide, S. \& Duff, R. 2006, 'What Causes Accidents?', Proceedings of the ICE - Civil Engineering, 159 (6), pp. 46-50

Guo, H. 2009, 'Rethinking Construction Project Management using the VP-Based Manufacturing Management Model' Thesis from the Department of Building and Real Estate, The Hong Kong Polytechnic University; Hong Kong.

Hare, B., Maloney, B., Cameron, I. \& Duff, A. R. 2005, 'Improving Consultation and Worker Engagement in the Construction Industry', Proceedings of the 2nd Scottish Conference for Postgraduate Researchers of the Built and Natural Environment, Glasgow: Caledonian University, pp. 151-160

Harper, A. C., Cordery, J. L., de Klerk, N. H., Sevastos, P., Geelhoed, E., Gunson, C., Robinson, L., Sutherland, M., Osborn, D. \& Colquhoun, J. 1997, 'Curtin Industrial Safety Trial: Managerial Behaviour and Program Effectiveness', Safety Science, 24 (3), 173-179.

Harris, F., McCaffer, R. \& Edum-Fotwe, F. 2006, Modern Construction Management, 6th Ed., Wiley-Blackwell, UK

Harvey, N. 2006, Global Change and Integrated Coastal Management: The Asia-Pacific Region, Springer, Australia, pp. 182.

Haslam, R. A., Hide, S. A., Gibb, A. G. F., Gyi, D. E., Pavitt, D., Aktinson, S. \& Duff, A. R. 2005, 'Contributing Factors in Construction Accidents', Applied Ergonomics, 36 (4), 401-415

Health and Safety Authority 2001, Code of Practice for Working in Confined Spaces Health and Safety Authority, Dublin, Ireland

Spillane, J and Oyedele, L (2013) 'Strategies for effective management of health and safety in confined site construction', Australasian Journal of Construction Economics and Building, 13 (4) 50-64 
Health and Safety Authority 2008, Use of Mobile Machinery on Construction Sites Information Sheet Health and Safety Authority, the Metropolitan Building, James Joyce Street, Dublin 1

Health and Safety Authority 2011, Plant and Equipment - Transport Management on Construction Sites Available at: http://www.hsa.ie/eng/Your Industry/Construction/Plant and Machinery/ Accessed on: 4th July, 2011

Health and Safety Executive 1996, Safety Signs and Signals - Guidance on Regulations London, Health and Safety Books, UK

Health and Safety Executive 2003, HSE Construction Blitz Targeting Mobile Plant, Vehicles and lifting Operations HSE Press Release, 21st of February 2003, Health and Safety Executive, UK

Health and Safety Executive 2009a, Health and Safety Induction for Smaller Construction Companies 2nd Ed., Crown Copyright, UK

Health and Safety Executive 2009b, Health and Safety Statistics 2007/08 Crown copyright, HSE Books, PO Box 1999, Sudbury, Suffolk: UK.

Health and Safety Executive 2010a, Statistics on Fatal Injuries in the Workplace 2009/10 Accessed on; 22nd June, 2010. Available at: http://www.hse.gov.uk/statistics/fatalinjuries.htm pp. 1.

Health and Safety Executive 2010b, Work-related Injuries and III Health in Construction Accessed on 22nd June, 2010, available at: http://www.hse.gov.uk/statistics/industry/construction/index.htm pp. 1.

Hegazy, T. \& Elbeltagi, E. 1999, 'EvoSite: Evolution-based Model for Site Layout Planning' Journal of Computing in Civil Engineering, 13 (3), 198-206

Holroyd, T. M. 1999, Site Management for Engineers, Thomas Telford, UK, pp. 77.

Holt, J. A. 2005, Principles of Construction Safety, Wiley-Blackwell, New Jersey, N.J., USA

Hyoung, J. I., Kwon, Y., Kim, S., Kim, Y., Su Ju, Y. \& Lee, H. 2009, 'The Characteristics of Fatal Occupational Injuries in Korea's Construction Industry 1997-2004', Safety Science, 47 (8), 1159-1162

International Labour Office 1999, Safety, Health and Welfare on Construction Sites - A Training Manual International Labour Organisation; Geneva, ISBN 92-2-109182-1, pp 1- 134

International Labour Organisation 2005, Joint Press Release ILO/WHO Number of Work related Accidents and Illnesses Continues to Increase ILO and WHO Join in Call for Prevention Strategies Press release, April, 2005, ILO/05/21.

Kartam, N. A., Flood, I. \& Koushki, P. 2000, Construction Safety in Kuwait: Issues, Procedures, Problems, and Recommendations', Safety Science, 36 (3), 163-184

Kelsey, J., Winch, G. \& Penn, A. 2001, Understanding the Project Management Process: Requirements Capture for the Virtual Construction Site Bartlett Research, paper number 15, University College London, UK.

Khalafallah, A. \& El-Rayes, K. 2004, 'Safety and Cost Considerations in Site Layout Planning', Housing and Building Research Centre Journal, 1 (1), 141-150

Lambeck, R. \& Eschemuller, J. 2008, Urban Construction Project Management, McGraw Hill Professional, USA

Langford, D., Rowlinson, S. \& Sawacha, E. 2008, 'Safety Behaviour and Safety Management: It's Influence on The Attitudes of Workers in the UK Construction Industry', Engineering Construction and Architectural Management, 7 (2), 133-140

Spillane, J and Oyedele, L (2013) 'Strategies for effective management of health and safety in confined site construction', Australasian Journal of Construction Economics and Building, 13 (4) 50-64 
Laurier, E. 2010, Participant Observation In: Clifford, N., French, S. \& Valentine, G. Key Methods in Geography, SAGE Publications Ltd., UK

Leopold, E. \& Leonard, S. 1987, 'Cost of Construction Accidents to Employers', Journal of Occupational Accident, 8 (4), 273-294

Long, N. D., Ogunlana, S., Qunag, T. \& Lam, K.C. 2004, 'Large Construction Projects in Developing Countries: A Case of Vietnam', International Journal of Project Management, 22 (7), 553-561

Loosemore, M \& Lee, P. 2002, 'Communication Problems with Ethnic Minorities in the Construction Industry', International Journal of Project Management, 20 (7), 517-524

Loosemore, M, Dainty, A. \& Lingard, H. 2003, Human Resource Management in Construction Projects: Strategic and Operational Approaches, Taylor and Francis, UK, pp. 211.

Mallasi, Z. \& Dawood, N .N. 2002, 'Registering Space Requirements of Construction Operations Using Site-PECASO Model', International Council for Research and Innovation in Building and Construction CIB w78 conference 2002, Aarhus School of Architecture.

Mawdesley, M. J., Al-jibouri, S., H., \& Yang, H. 2002, 'Genetic Algorithms for Construction Site Layout in Project Planning', Journal of Construction Engineering and Planning, 128 (5), 418-426

McDonald, N. \& Hrymak, V. 2002, Safety Behaviour in the Construction Sector: Report to the Health and Safety Authority, Dublin \& the Health and Safety Executive, Northern Ireland Health and Safety Executive, UK

Mitropoulos, P., Abdelhamid, T. S. \& Howell, G. A. 2005, 'Systems Model of Construction Accident Causation', Journal of Construction Engineering and Management, 131 (7), 816825

Mohamed, S. 2002, 'Safety Climate in Construction Environment', Journal of Construction Engineering and Management, 128 (5), 375-384

Mossey, D. 2009, Early Contractor Involvement in Building Procurement: Contracts, Partnering and Project Management, John Wiley and Sons, UK

Muslea, I, Minton, S. \& Knoblock, C. A. 2000, Selective Sampling with Redundant Views American Association for Artificial Intelligence, Proceedings of AAAl-2000, Austin, TX, AAAI Press, Menlo Park, CA, USA, pp. 621-626.

Ng, T. S., Cheng, P. K. \& Skitmore, M. R. 2005, 'A Framework for Evaluating the Safety Performance of Construction Contractors', Building and Environment, 40 (10), 1347-1355

Occupational Safety and Health Administration 2004, Permit-required Confined Spaces U.S.; OSHA Publications Office, U.S. Department of Labour, 200 Constitution Avenue, NW, N3101, Washington, DC.

Ogunlana, S. O., Promkuntong, K. \& Jearkjirm, V. 1999, 'Construction Delays in a FastGrowing Economy: Compare Thailand with other Economies', International Journal of Project Management, 14 (1), 37-45

Ojanen, K., Seppala, A., \& Aaltonen, M. 1988, 'Measurement Methodology for the Effects of Accident Prevention Programs', Scandinavian Journal of Work and Environmental Health, 14 (1), 95-96

Okpala, D. C. \& Aniekwu, A. N. 1988, 'Causes of High Costs of Construction in Nigeria', Journal of Construction Engineering and Management, 114 (2), 233-244

Olson, H. C., Fine, S. A., Myers, D. C. \& Jennings, M. C. 1981, 'The Use of Functional Job Analysis in Establishing Performance Standards for Heavy Equipment Operators', Personnel Psychology, 34 (2), 351-164

Spillane, J and Oyedele, L (2013) 'Strategies for effective management of health and safety in confined site construction', Australasian Journal of Construction Economics and Building, 13 (4) 50-64 
Pinto, A., Nunes, I. L. \& Riberio, R. A. 2011, 'Occupational Risk Assessment in Construction Industry - Overview and Reflection', Safety Science, 49 (5), 616-624

Ringen, K. \& Seegal, J. 1995, 'Safety and Health in Construction Industry', Annual Review of Public Health, 16, 165-188

Roberts, P. W. \& Sykes, H. 2000, Urban Regeneration: A Handbook, SAGE Publications, UK, pp. 27

Rowlinson, S., Mohamed, S. \& Lam, S.-W. 2003, 'Hong Kong Construction Foremen's Safety responsibilities: A Case Study of Management Oversight', Engineering, Construction and Architectural Management, 10 (1), 27-35

Sahli, B. P. \& Armstrong, C. W. 1992, 'Confined Space Fatalities in Virginia', Journal of Occupational Medicine, 34 (9), 910-917

Sawacha, E., Naoum, S. \& Fong, D. 1999, 'Factors Affecting Safety Performance on Construction Sites', International Journal of Project Management, 17 (5), 309-315

Sejas, M. 2009, The Importance of Site Induction Training, Ezine Articles, available at: http://ezinearticles.com/comment.php?The-Importance-of-Site-Induction-

Training\&id=3227052 accessed on 31st August 2011

Shain, M. 2004, 'The Duty to Prevent Emotional Harm at Work: Arguments from Science and Law, Implications for Policy and Practice', Science Technology Society, 24 (4), 305-315

Sharma, R. 2009, Lack of Space around Construction Site Delaying Airport Modernisation, The Indian Express Limited, Monday, August $17^{\text {th }}$, India

Song, L., Mohamed, Y. \& AbouRisk, S. M. 2009, 'Early Contractor Involvement in Design and Its Impact on Construction Schedule Performance', Journal of Management Engineering, 25 (1), 12-20

Spillane, J. P., Oyedele, L. O., Konanahalli, A., McKenna, E. \& Von Meding, J. K. 2009, 'Confined Site Construction: Issues Regarding Implementation of Health and Safety', $6^{\text {th }}$ International Conference on Innovation in Architecture, Engineering and Construction (AEC), The Nittany Lion, Pennsylvania State University, USA, June 9th - 11th.

Spillane, J. P., Oyedele, L. O., Von Meding, J. K. \& Konanahalli, A. 2010, Material Management within Confined Construction Sites, COBRA Conference, Dauphine University, Paris, France, 2nd \& 3rd September.

Spillane, J. P., Oyedele, L. O., Von Meding, J. K. \& Konanahalli, A. 2011a, Confined Site Construction: A Qualitative review of Issues Regarding Health and Safety On-site, Association of Researchers in Research Management (ARCOM), Conference in the University of the West of England, Bristol, UK on the 5th - 7th of September.

Spillane, J. P., Oyedele, L. O., Von Meding, J. K., Konanahalli, A., Jaiyeoba, B. E. \& Tijani, I K. 2011b, 'Confined Site Construction: A Qualitative Investigation of Critical Issues Affecting Management of Health and Safety', Journal of Civil Engineering and Construction Technology, 2 (7), 138-146

Tam, C. M., Tong, T. K. L., Leung, A. W. T. \& Chiu, G. W. C. 2002, 'Site Layout Planning using Non-Structural Fuzzy Decision Support Systems', Journal of Construction Engineering and Management, 128 (3), 220-231

Tan-Wilhelm, D., Witte, K., Liu, W. Y., Newman, L. S., Janssen, A., Ellison, C., Yancey, A., Sanderson, W. \& Henneberger, P. K. 2000, 'Impact of a Worker Notification Program: Assessment of Attitudinal and Behavioural Outcomes', American Journal of Industrial Medicine, 37 (2), 205-13

Teo, E. A. L., Ling, F. Y. Y. \& Chong, A. F. W. 2005, 'Framework for Project Managers to Manage Construction Safety', International Journal of Project Management, 23 (4), 329-341

Spillane, J and Oyedele, L (2013) 'Strategies for effective management of health and safety in confined site construction', Australasian Journal of Construction Economics and Building, 13 (4) 50-64 
Tindiwensi, D. 2000, Integration of Buildability Issues in Construction Projects in Developing Economies Department of Civil Engineering, Makerere University P. O. Box 7062, Kampala, Uganda.

Tommelein, I. D. \& Zouein, P. P. 1993, 'Interactive Dynamic Layout Planning', Journal of Construction Engineering and Management, 119 (2), 266-287

Trajkovski, S. \& Loosemore, M. 2006, 'Safety Implications of low-English Proficiency among Migrant Construction Site Operatives', International Journal of Project Management, 24 (5), 446-452

United Nations 2008, World Urbanisation Prospects: The 2007 Revision - Highlights Department of Economic and Social Affairs - Population Division, USA

United Nations, 2010, World Urbanisation Prospectus: The 2009 Revision - Highlights Department of Economic and Social Affairs - Population Division, USA

Varghese, K. \& O'Connor, J. T. 1995, 'Routing Large Vehicles on Industrial Construction Sites', Journal of Construction Engineering and Management, 121 (1), 1-12

Westfall, L. 2009, The Certified Software Quality Engineer Handbook, ASQ Quality Press (In press)

Wideman, R. M. 1990, Total Project Management of Complex Projects Improving Performance with Modern Techniques Presentation to the Construction Industry in the cities of Bangalore, Bombay, Calcutta, Madras and New Delhi on behalf of the Consultancy Development Centre New Delhi, India

Winch, G. 2010, Managing Construction Projects, $2^{\text {nd }}$ Ed., John Wiley and Sons, USA, pp. 284 